\title{
On the possibility of obtaining high-quality lyophilized collagen hydrolysate and its applicability in the sausage production
}

\author{
Aleksandr LUKIN ${ }^{1 \star}$
}

\begin{abstract}
The paper discusses the issues of rational use of secondary collagen-containing raw material in the food industry, namely cattle by-products. The technology of obtaining collagen hydrolysate from this type of raw material with the subsequent freeze-drying is proposed, which maximizes the level of preservation of native properties and the expands the scope of its application. The paper presents the stages of obtaining lyophilized collagen hydrolysate by biomodification of frozen cattle lips and ears. The preparation of lyophilized collagen hydrolysate was carried out as follows: the lips and ears were preliminary washed in running tap water for 20 minutes in order to remove mucus and impurities, muscle and adipose tissue was also removed; after draining (15-20 minutes), the raw material was ground on a top with a grid diameter of 2-3 $\mathrm{mm}$. At the next stage, the crushed lips and ears were treated with a solution of Protepsin enzyme preparation in the ratio of the raw material to solution $1: 2$ and kept for $0.5-1.5$ hours at a concentration of the enzyme preparation of $0.06 \%$ by weight of the raw material, while stirring periodically (at $17-22^{\circ} \mathrm{C}$ ). The filtrate from the product was separated on a sieve. Processed as described above, the raw material was subjected to freeze-drying. Evaluation of the temperature and duration of freeze-drying of collagen hydrolysate was carried out at a drying layer thickness of $5.0 \mathrm{~mm}$ and different drying temperatures: $20^{\circ} \mathrm{C}, 30^{\circ} \mathrm{C}, 40^{\circ} \mathrm{C}$, and $50^{\circ} \mathrm{C}$.
\end{abstract}

Keywords: enzyme preparation; freeze-drying; functional and technological properties; collagen-containing raw material; meat processing industry.

Practical Application: Processing of secondary collagen-containing products of the meat industry.

\section{Introduction}

Most food products have quite a limited shelf life due to the activity of microorganisms and enzymes. One of the methods to suppress the microorganisms growth and enzymatic activity in the product is to remove the moisture drying the it in an artificial or natural way. Mold fungi and bacteria develop in products with a moisture content of $10 \%$ to $30 \%$ (Bianchini \& Bullerman, 2009). To increase the raw material shelf life, it is necessary to bring the moisture content of the product to a level that prevents the development of microorganisms.

Raw materials of animal origin, by contrast, have less moisture and more dry matter.

Animal proteins are natural products, whose production is based on thermal (degreasing, dehydration) and mechanical (grinding) processes.

Animal proteins are obtained from various raw materials: pork skins, pork veins, beef veins, pork or beef blood plasma, whey, and so on.

It should be noted that collagen is a group of proteins of natural origin obtained from the muscle and connective tissues of animals. This is the main component of connective tissue and the most common protein in mammals, comprising 25-v35\% of the proteins in the whole body. Collagen, in the form of elongated fibrils, is mainly found in fibrous connective tissues such as ligaments, tendons and skin, as well as in large quantities in the cornea, cartilage, bones, blood vessels, intestines, and intervertebral discs.

Due to their chemical composition and functional properties, animal proteins are an alternative to soy isolated proteins and can be used in the production of meat products as a substitute for meat, increase nutritional and biological value, improve organoleptic properties, enhance meat taste, and reduce the cost of meat products (Vidal et al., 2018).

Using animal proteins obtained from collagen-containing raw materials allows to enrich meat products with dietary fiber, significantly improving the rheological properties of food products, especially the texture. The high functional properties of animal proteins are manifested in their water-holding capacity (Araujo et al., 2018).

The problem of preserving the quality of the obtained raw materials has always remained critical, so new methods of preserving it are being developed. At a later stage, we looked into the problem of obtaining collagen hydrolysate in a dry form, crushed to powder. The use of the product in the form of dry powder opens up encouraging prospects for both expanding the scope of its application and increasing the shelf life. When choosing the method of preservation of raw materials, we addressed the 
problem of the maximum preservation of organoleptic, physical, chemical, functional and technological indicators, as well as ensuring long shelf life of processed raw materials.

Drying seems the most promising among many ways to preserve raw materials.

There are many ways of drying raw materials of plant and animal origin: cabinet drying, drum and convection drying, freeze-drying (lyophilization), vacuum-pulse, infrared, microwave drying, etc.

Among the hundreds of engineering solutions and processes used nowadays, there are two principal directions: atmospheric drying and vacuum drying. Atmospheric drying has a significant drawback, i.e. it implies a long-term high-temperature contact of the product with the oxygen in the air (Wenfeng et al., 2013). This leads to intense oxidative reactions and, as a consequence, to the low quality of many dry products. Therefore, at present, vacuum drying at pressures below the triple point of water (freeze-drying), or vacuum moisture evaporation, is becoming more widespread (Haseley \& Oetjen, 2017).

The analysis of modern drying methods allows us to conclude that the most gentle method of dehydrating biological objects is freeze-drying (lyophilization) (Nireesha et al., 2013).

The products produced with the freeze-drying technology are stored and transported at room temperature, thus no cold chains are needed. Compared with food products produced with the heated-air drying, vacuum drying, and spray drying methods, those produced with the freeze-drying method has brighter color and higher nutritional value, and is easier to digest, preserving the nutrients and color, flavor and taste of the meat to the greatest extent (Huan et al., 2005; Kotwaliwale et al., 2007). Therefore, it is especially suitable for drying non-staple food which is extremely sensitive to heat and easy to be oxidized. Freeze drying does not damage the protein in meat and causes no loss of fat-soluble vitamin such as Vitamin A and Vitamin D (Juan \& Yuanzhi, 2012; Chen, 2008). By-products and meat processed in this way can totally replace fresh food in terms of nutrition supply.

The principle of lyophilization is to dehydrate biological objects in a frozen state under vacuum. During freeze-drying, the moisture is removed by an ice-steam phase transition. The major amount of moisture (75-90\%) is removed when ice sublimates at temperatures below $0{ }^{\circ} \mathrm{C}$, and only the residual moisture is removed when the material is heated to $40-60{ }^{\circ} \mathrm{C}$ (Papavasiliou et al., 2008).

Freeze-drying is carried out in three steps. The first step is the freezing of the biological material, during which $10-15 \%$ of all moisture evaporates from the object as the heat is released due to ice melting when water freezes. The second step (sublimation) is characterized by a constant drying rate of the object. At this time, the major moisture is removed. The third step is residual moisture removal, characterized by a falling drying rate, when the temperature of the object becomes positive. At this step, the bound moisture that is not frozen in the object is removed. Drying rate depends on the intensity of heat supply. The temperature of the object gradually increases to the environment one.
Freeze-drying somewhat changes the properties and quality of the product. However, other methods of preservation change the properties of the raw materials more dramatically. The main advantages of freeze-dried foods are: high palatability and biological full-value; fast restorability; low weight; long-term storage under various conditions without the use of cold, which largely determines the purpose of these products and makes this type of drying preferable (Fissore \& Pisano, 2015).

The purpose of this study is to investigate and develop the manufacturing technology of lyophilized collagen hydrolysate $(\mathrm{LCH})$ and to study functional and technological properties of model forcemeat systems with LCH.

\section{Materials and methods}

The study subjects in this paper are:

- enzyme preparation Protepsin (standard proteolytic activity is 100 units/g) produced by ZAO Zavod Endokrinnykh Fermentov, Rzhavki settlement, Solnechnogorsky district, Moscow region, in accordance with TU 9219-005-427892572005, Hygiene Certificate No. 50.16.01.000.M.000638.10.07 dated October 19, 2007 (State Committee for Standards and Product Quality Management, 1989);

- collagen from the connective tissue of the cattle lips and ears;

- collagen hydrolysate $(\mathrm{CH})$;

- lyophilized collagen hydrolysate (LCH);

- forcemeat systems.

At the first stage, $\mathrm{CH}$ properties were studied using a collagen-containing raw material obtained from the cattle lips and ears. $\mathrm{CH}$ from the lips and ears was obtained as follows. The lips and ears were preliminary washed in running tap water for 20 minutes in order to remove mucus and impurities, muscle and adipose tissue was also removed; after draining (15-20 minutes), they were ground on a top with a grid diameter of 2-3 mm (Singh et al., 2018). At the next stage, the crushed lips and ears were treated with a solution of Protepsin enzyme preparation in the ratio of raw materials to solution 1:2 and kept for 0.5-1.5 hours at a concentration of the enzyme preparation of $0.06 \%$ by weight of the raw material, while stirring periodically (at $17-22^{\circ} \mathrm{C}$ ). The filtrate from the product was separated on a sieve.

Processed as described above, the raw material was subjected to freeze-drying on Bio-Rus-7FD.

The design includes two systems: vacuum treatment and cold supply. The first of them allows to implement the traditional vacuum-freeze-drying by "ice-steam" phase transition, the second - dehydration by vacuum evaporation. These two modes can also be combined within a single drying cycle, with any combination of the duration of each of them.

Bio-Rus-7FD has the following technical parameters: evaporation capacity - up to $3.5 \mathrm{~kg} / \mathrm{cycle}$; total area of work shelves $-0.48 \mathrm{~m}^{2}$; heating temperature of electric heaters - up to $300{ }^{\circ} \mathrm{C}$; desublimator plates cooling temperature - up to 
$-40^{\circ} \mathrm{C}$; the residual chamber pressure (depending on the surface temperature of the desublimator and the capacity of the heat sink to the raw material to be dried) for freeze-drying - from 0.1 to $0.5 \mathrm{~mm} \mathrm{Hg}(13.33-66.65 \mathrm{~Pa})$.

The raw material was placed on metal sheets, which were then placed in a freezer with a temperature of $-18 \pm 1{ }^{\circ} \mathrm{C}$ and natural air circulation.

At this stage, the freeze drying parameters (temperature and layer thickness) of the $\mathrm{CH}$ were set.

Functional and technological properties (moisture-retaining capacity (MRC), fat-retaining capacity (FRC), emulsifying capacity (EC)) of model forcemeat systems were determined according to recommendations (Skurikhin \& Tutelyan, 1998). Moisture-binding capacity (MBC) was evaluated by Grau and Hamm method modified by V.P. Volovinskon and B.I. Kelman (Skurikhin \& Tutelyan, 1998).

Dynamic viscosity ( $\eta$, Pas) of model forcemeat systems was determined on RHEOTEST 2.1 viscometer (Germany) according to the device manual, using the viscometer rotor. Dynamic viscosity in all samples was determined at $20^{\circ} \mathrm{C}$.

The mass fraction of hygroscopic moisture in the raw material was determined by drying the samples at $100-105^{\circ} \mathrm{C}$ for 3 hours.

Mass fraction of fat in the model forcemeat was determined using the Soxhlet extractor.

The mass fraction of minerals was determined after burning organic matter in a muffle furnace at $500{ }^{\circ} \mathrm{C}$ for $5-6$ hours to constant weight.

The mass fraction of protein was determined by the photometric method.

Adhesion properties of model forcemeat systems were determined in a laboratory unit according to the method of S.I. Tyshkevich (Skurikhin \& Tutelyan, 1998). The method determines the amount of force required to separate the two surfaces connected by the forcemeat under test.

Moisture retaining capacity (MRC) is estimated by determining the difference between the mass fraction of moisture in the forcemeat and the amount of moisture separated during the heat treatment.

Fat retaining capacity (FRC) is defined as the difference between the mass fraction of fat in the forcemeat and the amount of fat separated during the heat treatment.

Emulsifying capacity (EC) is the ratio of the emulsified oil volume to the total oil volume in the system. This definition includes the concept of emulsion stability which manifests itself over the period from the end of emulsification to the time of measuring under fixed experimental conditions.

\subsection{Experimental design and statistical analysis}

All analyses were carried out in triplicate unless otherwise stated and the average values were calculated. The results were expressed as mean value \pm standard deviation. Significant differences between mean values at significance level $p<0.05$ were established using the One-way analysis of variance and Student's test. Microsoft Excel version 2010 was used as the statistical analysis software.

\section{Results and discussion}

Evaluation of the temperature and duration of $\mathrm{CH}$ freeze-drying was carried out at a drying layer thickness of $5.0 \mathrm{~mm}$ and different drying temperatures: $20^{\circ} \mathrm{C}, 30^{\circ} \mathrm{C}, 40^{\circ} \mathrm{C}$, and $50^{\circ} \mathrm{C}$. The curves of $\mathrm{CH}$ lyophilization at different heating temperatures are shown in Figure 1.

Figure 1 suggests that an increase in heating temperature results in a decrease in drying time and moisture content of $\mathrm{CH}$ : at $20^{\circ} \mathrm{C}, 30^{\circ} \mathrm{C}$, and $40{ }^{\circ} \mathrm{C}$ freeze-drying lasted for about 270 minutes, with $14.0 \%$ mass fraction of moisture in the final

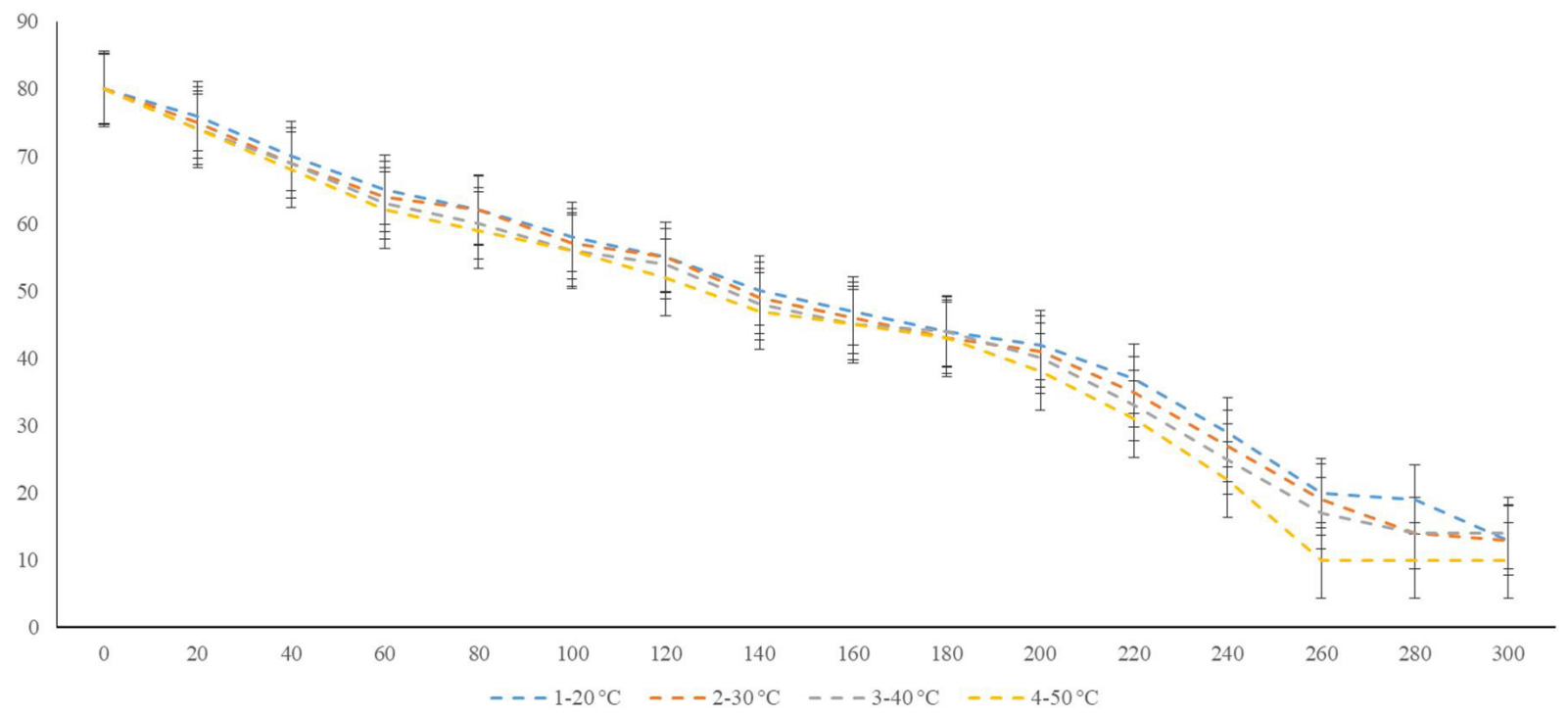

Figure 1. Lyophilization curves of $\mathrm{CH}$ at temperatures: $1-20^{\circ} \mathrm{C} ; 2-30^{\circ} \mathrm{C} ; 3-40{ }^{\circ} \mathrm{C} ; 4-50{ }^{\circ} \mathrm{C}$. 
product. However, the drying time at $50^{\circ} \mathrm{C}$ is 260 minutes, the moisture content in $\mathrm{LCH}$ was $10.0 \%$. Thus, the temperature of $\mathrm{CH}$ freeze-drying of $50^{\circ} \mathrm{C}$ and the duration of lyophilization of 260 minutes were chosen for further studies. An important parameter of freeze-drying is the thickness of the product layer. In this work, the LCH curves were obtained at a heating temperature of $50^{\circ} \mathrm{C}$ and different layer thickness (Figure 2).

From Figure 2 it follows that an increase in the thickness of the $\mathrm{CH}$ layer led to an increase in the duration of drying and the mass fraction of moisture in the final hydrolyzate. Thus, with a layer thickness of 5.0,10.0,15.0, and $20.0 \mathrm{~mm}$, the duration of lyophilization was $260,280,280$, and 300 minutes, while the moisture content was $20.0,26.0,27.0$, and $30.0 \%$, respectively. $5.0 \mathrm{~mm}$ thickness of the drying layer is considered to be optimum.

Thus, the parameters of $\mathrm{CH}$ freeze-drying were as follows: heating temperature $-50{ }^{\circ} \mathrm{C}$; drying time -260 minutes; drying layer thickness $-5.0 \mathrm{~mm}$.

The obtained product was in the form of plates 3-6 $\mathrm{mm}$ thick of negligible porosity (pores were distributed evenly throughout its volume) and had a solid structure subject to breaking. This fact suggests that oxidative and hydrolytic processes will be slower in the product, which will increase its shelf life, and the uniformity of the pores will contribute to better moisture absorbtion, which, in turn, will affect the degree of hydration. The dried product plates were ground to powder.

To study the applicability of LCH in the technology of forcemeat products, it was necessary to determine the most rational introduction of the obtained LCH into the model forcemeat systems. The amount of $\mathrm{LCH}$ replacing the forcemeat was $5 \%, 10 \%, 15 \%$, and $20 \%$.

Forcemeat is a complex heterogeneous system, the functional properties of which depend on the ratio of tissues, and the content of specific proteins, fats, water, and morphological components in such tissues.
The muscle tissue in meat has a significant impact on the FTP, since it consists of a complex of structurally different proteins. In the aspect of functional properties during obtaining meat products, the combination of muscle proteins is responsible for the efficiency of meat emulsions formation. The quantity of protein in the system, its qualitative composition, and environmental conditions predetermine the stability of the resulting meat systems, influencing structural, mechanical, and organoleptic characteristics (Neklyudov \& Ivankin, 2007).

Functional and technological properties (FTP) of a meat raw material are understood as a set of indicators characterizing the levels of MBC, MRC, FRC, EC, structural and mechanical properties (stickiness, viscosity, plasticity, etc.), sensory characteristics (color, taste, smell), the yield and loss during heat treatment of various types of raw materials and meat systems. These indicators have a priority in determining acceptability of meat for food production.

The functional properties of isolated proteins are commonly understood as a wide range of physical and chemical characteristics that determine their behavior during processing and storage, providing the desired structure, technological and consumer properties of finished products (Aylangan \& Öztan, 2008).

Functional and technological indicators of model forcemeat systems before heat treatment are given in Figure 3.

The data obtained indicate an increase in $\mathrm{MBC}$ and plasticity of model meat systems. MBC values ranged from $79.78 \%$ to $85.13 \%$. Probably, there occurred a change in the spatial availability of charged groups of proteins, which caused loosening of the protein structure, since repulsion of like-charged amino acid residues led to the expansion of the space between polypeptide chains and increases the availability of active centers of the protein macromolecule, which allowed them to attract dipoles of water molecules, forming a solvation (hydration) shell. The forcemeat in the system became more yielding, due

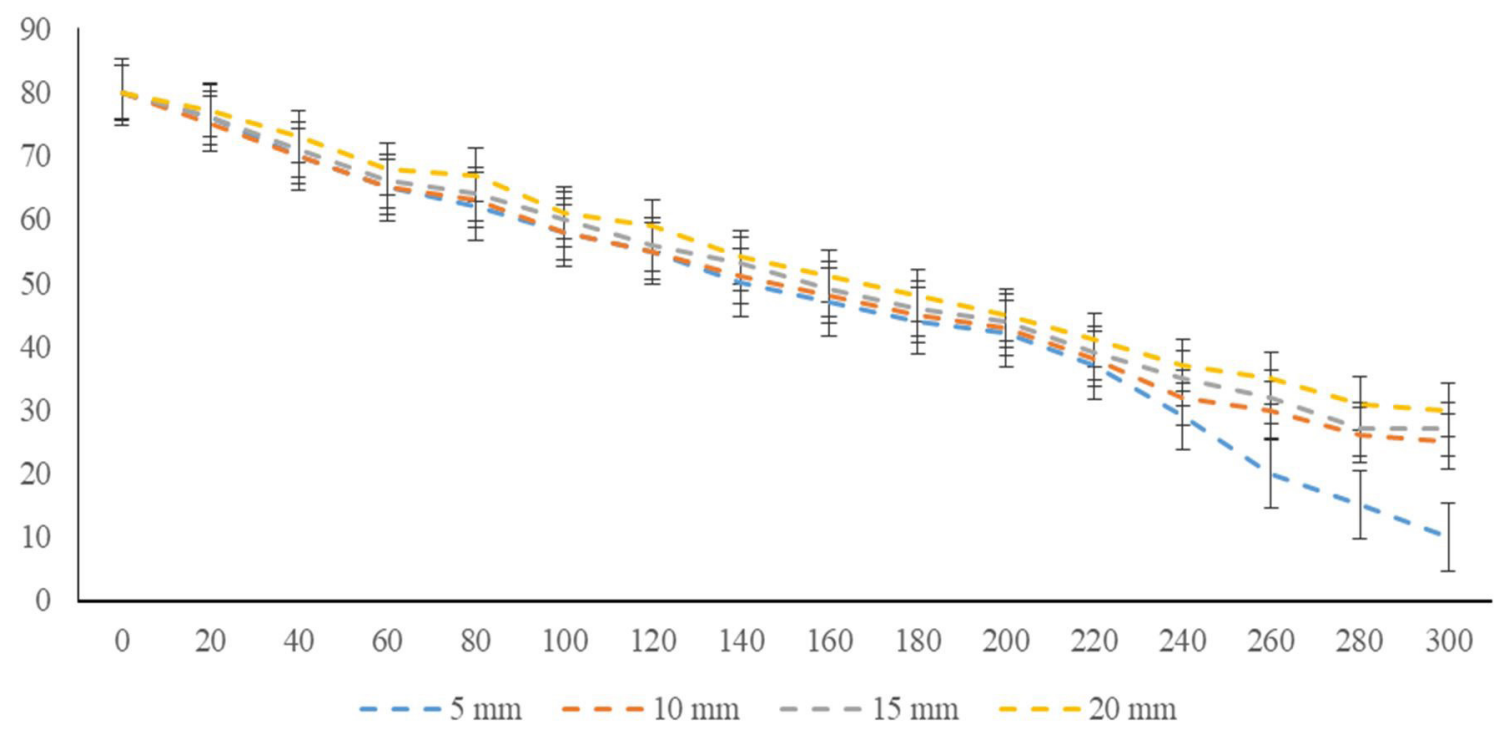

Figure 2. LCH Curves at heating temperature of $50{ }^{\circ} \mathrm{C}$ and different thickness of product layer: 1-5.0 mm; 2-10.0 $\mathrm{mm}$; 3-15.0 mm; 4-20.0 mm. 


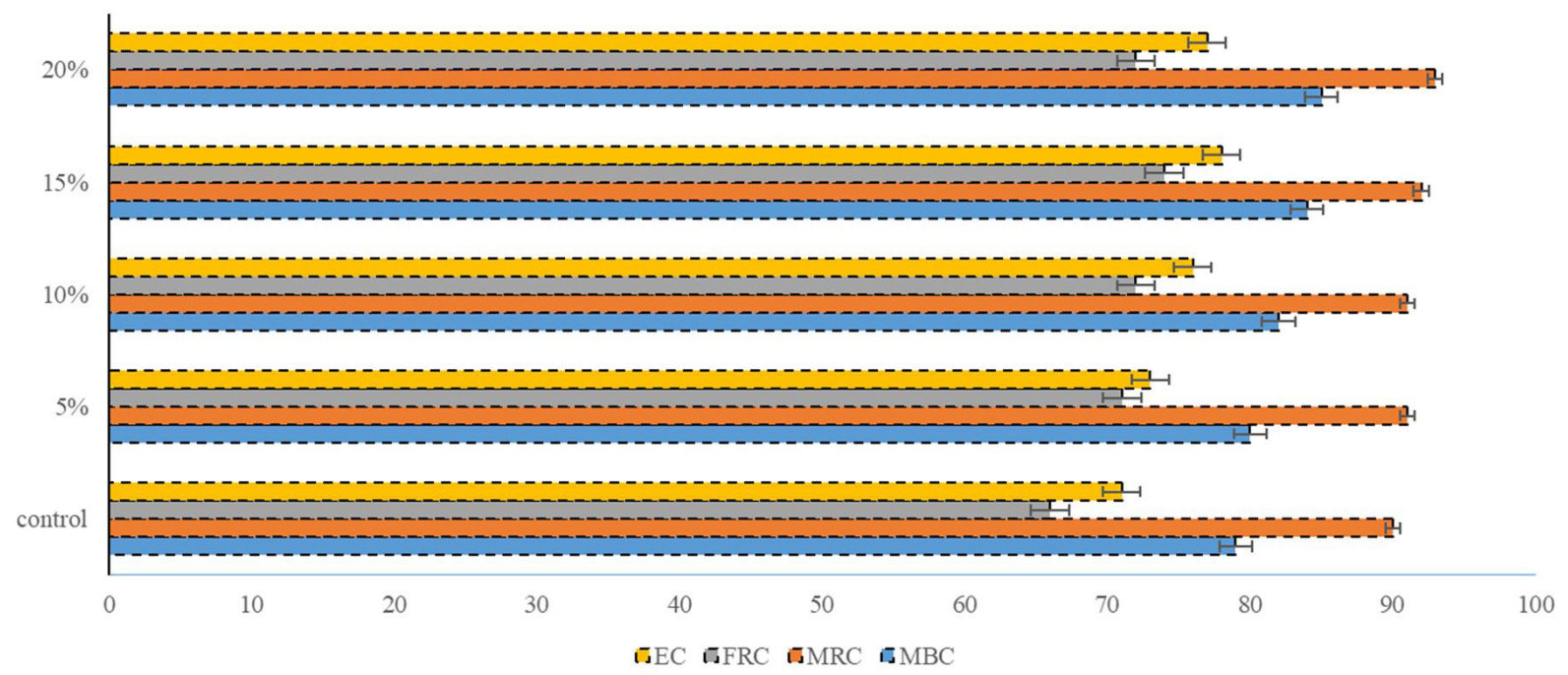

Figure 3. FTP of model forcemeat systems before heat treatment.

to the interaction of dispersed collagen molecules with water. MRC of the formula compositions with the added $\mathrm{LCH}$ ranged from $90.11 \%$ to $93.56 \%$. The data obtained indicate that there was no apparent dependence of the MRC upon the amount of $\mathrm{LCH}$ introduced into the test sample.

The FRC indicators also remained at the same level in the test samples, which is explained by the way the ground meat components were laid in the cutter. However, the test sample with $15 \%$ replacement of raw meat with $\mathrm{LCH}$ showed the maximum FRC value of $73.95 \%$.

EC indicators in all test samples were in the same percentage.

By nature, forcemeat has a certain viscosity. The rheological properties of such systems vary depending on shear stress, forcemeat properties and other factors (Bhaskar et al., 2008). The change in the plasticity of forcemeat mainly depends on the formula components in the system. The main characteristics of any forcemeat is a combination of elastic, plastic or viscous-plastic properties.

Due to the interaction of van der Waals cohesive forces, coagulatory bonds in disperse systems are formed by the interaction between particles and molecules through the layers of the dispersion sphere. The thickness of the layers is characterized to a certain extent by the content of the dispersion medium (Bobuş, 2010). With increasing water content, the values of the shear properties gradually decreased, as indicated by the data presented in Figure 4.

The diagram confirms that an increase in LCH amount in the system led to a shift in the ultimate shear stress. The resulting $\mathrm{LCH}$ contributed to the formation of structures in the protein-fat system, thereby contributing to an increase in the tenderness of model forcemeat systems compared to the samples produced without the food additive.

Model forcemeat with the addition of $20 \% \mathrm{LCH}$ instead of raw meat had a smearing consistency close to the one of paste forcemeat. The addition of $15 \% \mathrm{LCH}$ to the forcemeat formula was considered to be the best choice.

The introduction of a high proportion of $\mathrm{LCH}$ caused an insignificant decrease in the mass fraction of protein in the model forcemeat systems under study, which is explained by the low content of free peptides and amino acids in the chemical composition of LCH compared to beef and pork forcemeat.

«Lyubitelskoye» boiled sauasage with added LHC was used as the basic formula (Table 1).

Figure 5 shows the properties of forcemeats of model meat systems obtained in accordance with the specified options.

At the maximum values of mass fraction of fat and ash in the control sample (10.99 and $0.98 \%$ ), the following trend was observed: with an increase in LCH replacing beef and pork in the model forcemeat systems, there occurred their slight decrease. In the test sample these values are 8.9 and 0.91 , respectively.

The water-to-protein ratio increased (from 3.98 in the control, to 4.37 in $20 \%$ replacement option) with an increase in the amount of $\mathrm{LCH}$ in the system. According to the literature data, the water-to-protein ratio in the resulting composition is somewhat high with respect to the optimal, ranging from 3.0 to 3.5 (Antipova et al., 2008).

During heat treatment, the amount of moisture and protein will be lost due to evaporation.

In the process of cutting sausage meat, there may form an adhering layer on the surface of the cutter and the main cutting mechanisms. Reducing the adhesion properties of forcemeat is a major task in the meat production, because of the products losses due to an adhering forcemeat layer on the equipment walls (Dieterich et al., 2014; Spohner et al., 2015). Laboratory studies of the test samples adhesion properties (Figure 6) showed that the formulas with prevailing pork are characterized by minimal adhesion indices. This is primarily due to the high content of adipose tissue, which contributes to the formation of a coagulation 


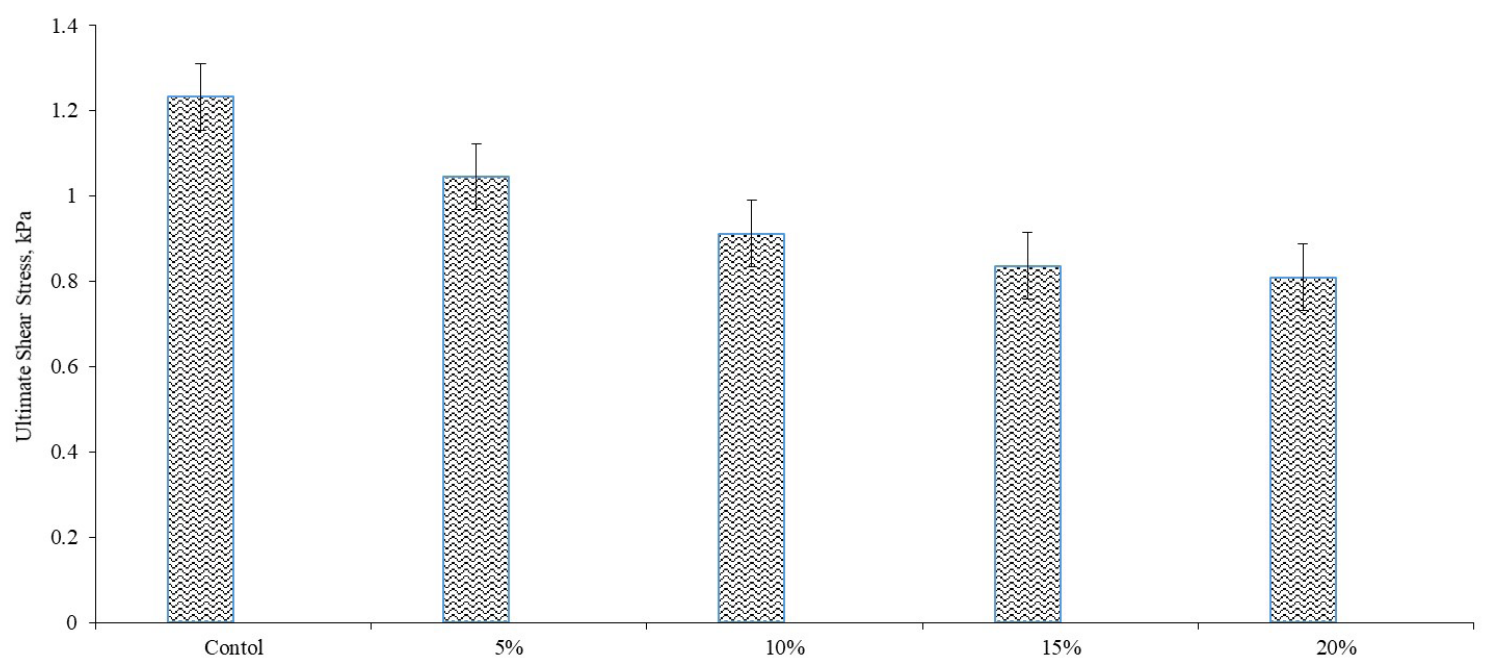

Figure 4. The change in the ultimate shear stress of model forcemeat.

Table 1. Formula of control and test samples.

\begin{tabular}{ccr}
\hline Raw material & \multicolumn{2}{c}{ Boiled sausage } \\
\cline { 2 - 3 } & kg per 100 kg of unsalted raw material & «Lyubitelskoye» with added LHC \\
\hline Trimmed beef, grade 1 & 35.0 & 30.0 \\
Semi-fat trimmed pork & 40.0 & 30.0 \\
Pork mid-back fat & 25.0 & 25.0 \\
LHC & - & 15.0 \\
& g per $\mathbf{1 0 0 ~ k g ~ o f ~ u n s a l t e d ~ r a w ~ m a t e r i a l ~}$ & 5.6 \\
Sodium nitrite & 5.6 & 110.0 \\
Granulated sugar & 110.0 & 85.0 \\
Ground black pepper & 85.0 & 55.0 \\
Nutmeg & 55.0 & 2500.0 \\
Salt & 2500.0 & \\
\hline
\end{tabular}

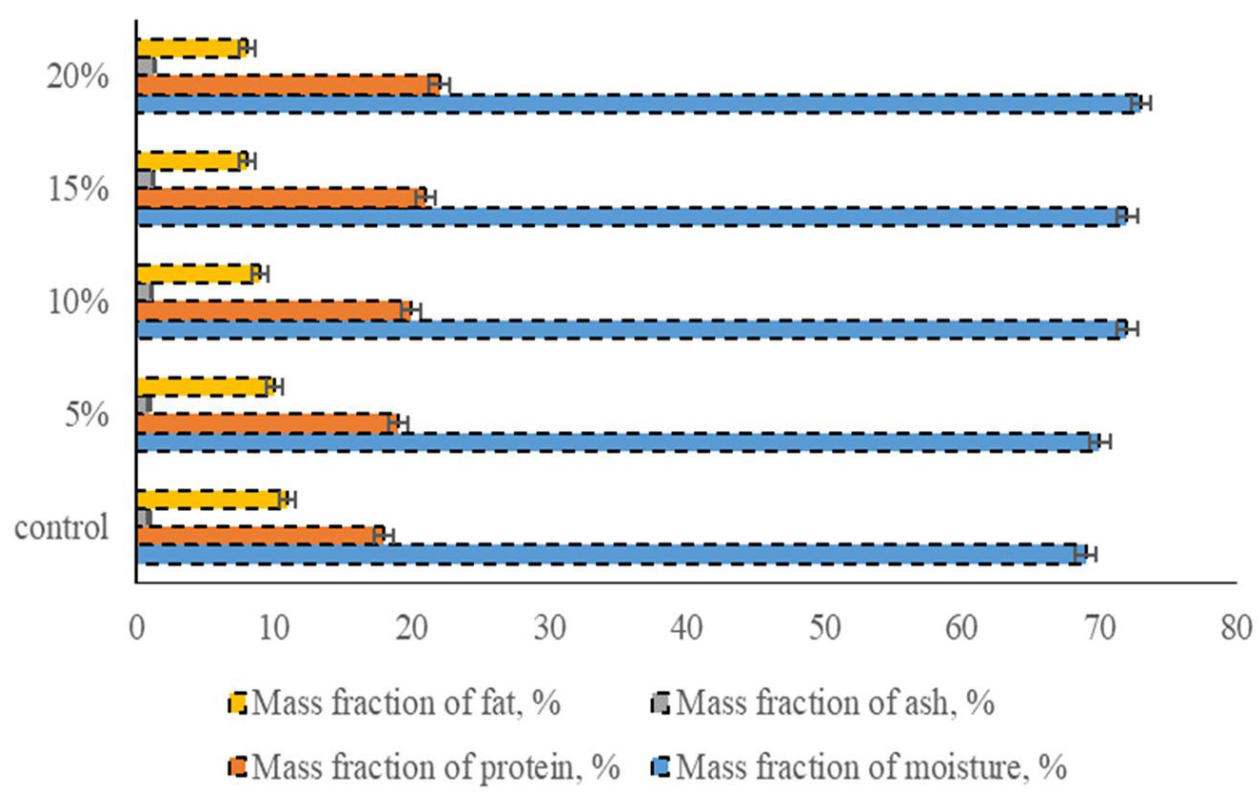

Figure 5. Physical and chemical indicators of model meat systems. 


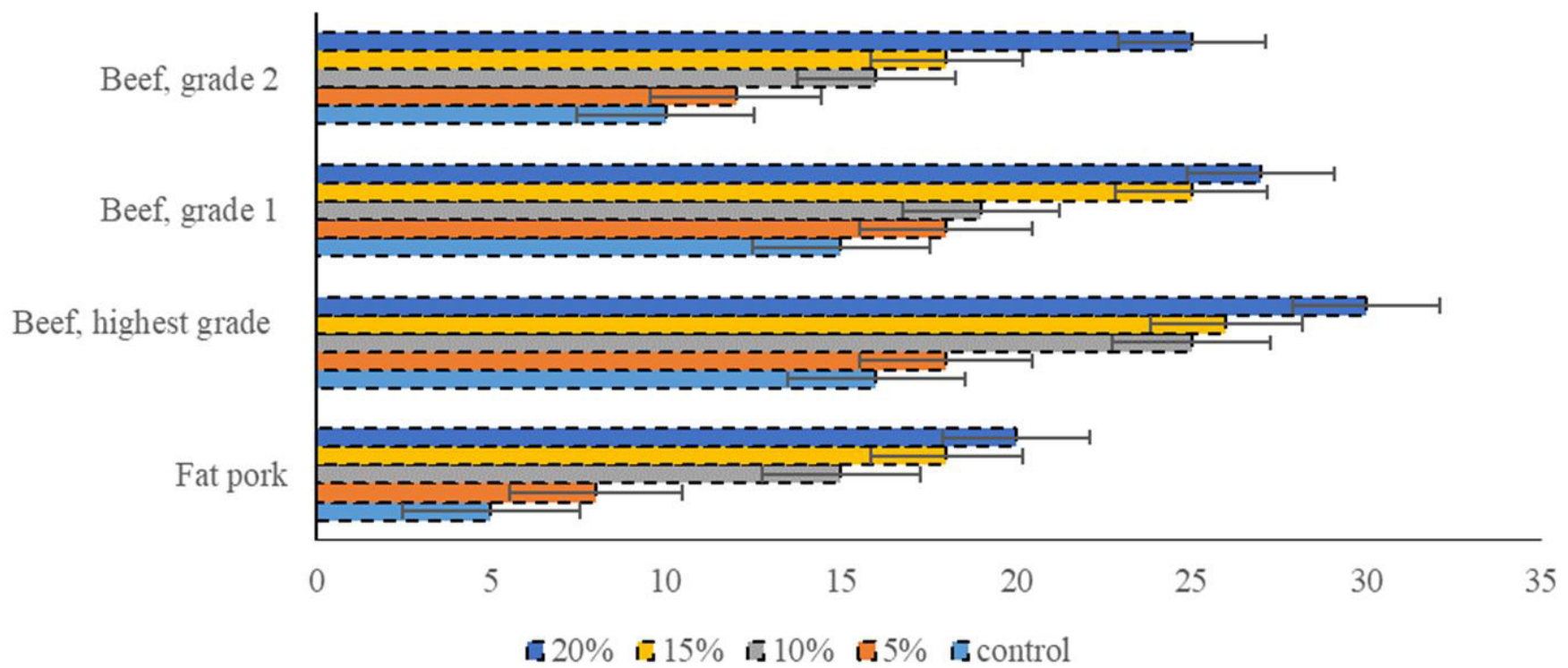

Figure 6. Adhesion properties of model forcemeat.

structure of the forcemeat during grinding. Introduced LCH has positively proved itself as a component with good plasticizing properties - the more LCH was introduced, the higher forcemeat adhesion properties were.

The obtained data on the functional and technological properties of the $\mathrm{LCH}$ suggest that $15 \%$ is the optimal amount of LCH introduced into the forcemeat, contributing to an increase in $\mathrm{MBC}$, adhesive properties of the forcemeat and the plasticity of meat systems.

The use of connective tissue of the lips and ears of cattle, subjected to enzymatic treatment, allows to obtain high-quality collagen preparations. Subsequent freeze-drying provides a high level of long-term preservation of all active ingredients of the product, and allows grinding it to powder.

\section{Conclusion}

The use of collagen in the food industry is limited due to its poor digestibility and accessibility, as well as the lack of some essential amino acids, for example tryptophan, in its composition. It is known that connective tissue proteins, collagen in particular, have the properties of dietary fiber, which can improve metabolism in the human body as a whole, including the functioning of the gastrointestinal tract.

That is why methods are being intensively developed for the integrated processing of collagen-containing raw materials, with a view to its use in the production of safe food products with specified quality indicators, including functional and technological ones. The most promising method, in our opinion, is biomodification by an enzyme preparation, which allows to convert the connective tissue components into a soluble and easily digestible state and thereby increase the efficiency of their use.

At the final stage, the collagen hydrolysate was freeze-dried in order to maintain quality and safety indicators.
The obtained results suggest that this type of drying has a positive effect on the properties of the raw material, while maintaining all its quality characteristics, without damaging its original structure. The results of the study are of great practical importance, since freeze-drying today is a unique technology that helps preserve the biological full-value of food products and ensure a long shelf life.

In the course of the work, the following parameters were set for $\mathrm{CH}$ freeze-drying: heating temperature $-50{ }^{\circ} \mathrm{C}$; drying time -260 minutes; drying layer thickness $-5.0 \mathrm{~mm}$. MRC of formulas with added LCH ranged from $90.11 \%$ to $93.56 \%$. The FRC indicators also remained at the same level in the test samples, which is explained by the way the ground meat components were laid in the cutter. However, the test sample with $15 \%$ LCH replacement of raw meat showed a maximum FRC value of $73.95 \%$.

The study of LHC applicability in the sausage production it was necessary to determine the most rational amount of the obtained LHC to be introduced into the model forcemeat systems. The amount of LHC introduced instead of the forcemeat was $5 \%, 10 \%, 15 \%$, and $20 \%$.

The model forcemeat with $20 \% \mathrm{LCH}$ instead of raw meat had a smearing consistency close to the one of paste forcemeat. $15 \% \mathrm{LCH}$ added to the forcemeat formula was considered to be the best option.

It follows from the above that the use of $\mathrm{LCH}$ in sausage technology not only improves the FTP, but also creates biologically active complexes for the enrichment of meat products with protein, so as to save the raw material.

\section{Acknowledgements}

The work was supported by Act 211 of the Government of the Russian Federation, contract No 02.A03.21.0011. 


\section{References}

Antipova, L. V., Podvigina, I. N., \& Kosenko, I. S. (2008). Use of enzyme preparations in the meat production process. Fundamental Research, 6, 134-135.

Araujo, I. B. S., Bezerra, T. K. A., Nascimento, E. S., Gadelha, C. A. A., Santi-Gadelha, T., \& Madruga, M. S. (2018). Optimal conditions for obtaining collagen from chicken feet and its characterization. Food Science and Technology (Campinas), 38(Suppl 1), 167-173. http:// dx.doi.org/10.1590/fst.27517.

Aylangan, A., \& Öztan, A. (2008). Protein hydrolysate production using by-products of animal food industry. Turkey 10. In Food Congress. Erzurum: Kahramanmaras Sutcu Imam University Esenyurt Üniversitesi Avsar Kampusu.

Bhaskar, N., Benila, T., Radha, C., \& Lalitha, R. G. (2008). Optimization of enzymatic hydrolysis of visceral waste proteins of Catla (Catlacatla) for preparing protein hydrolysate using a commercial protease. Bioresource Technology, 99(2), 335-343. http://dx.doi.org/10.1016/j. biortech.2006.12.015. PMid:17303414.

Bianchini, A., \& Bullerman, L. B. (2009). Biological control of molds and mycotoxins in foods. In ACS Symposium Series (pp. 1-16). Washington: American Chemical Society. http:// dx.doi.org/10.1021/ bk-2009-1031.ch001.

Bobuş, G. (2010). Determination of functional and bioactive properties of lentil protein concentrate and hydrolysate (Master's thesis). Mersin: Mersin University.

Chen, Y. (2008). Optimization of vacuum freeze-drying technologies of longan fruits. Nongye Gongcheng Xuebao (Beijing), 24(9), 244-248.

Dieterich, F., Boscolo, W. R., Pacheco, M. T. B., Silva, V. S. N., Gonçalves, G. S., \& Vidotti, R. M. (2014). Development and characterization of protein hydrolysates originated from animal agro industrial byproducts. Journal of Dairy, Veterinary \& Animal Research, 1(2), 1-7. http://dx.doi.org/10.15406/jdvar.2014.01.00012.

Fissore, D., \& Pisano, R. (2015). Computer-aided framework for the design of freeze-drying cycles: optimization of the operating conditions of the primary drying stage. Processes, 3(2), 406-421. http://dx.doi.org/10.3390/pr3020406.

Haseley, P., \& Oetjen, G.-W. (2017). Freeze-drying (3rd ed., 437 p.). Weinheim: Wiley-VCH.

Huan, Y. J., Zhou, G. H., Zhao, G. M., Xu, X., \& Peng, Z. (2005). Changes in flavor compounds of drycured Chinese Jinhua ham during processing. Meat Science, 71(2), 291-299. http://dx.doi. org/10.1016/j.meatsci.2005.03.025. PMid:22064228.
Juan, W., \& Yuanzhi, L. (2012). Comparison of volatiles of banana powder dehydrated by vacuum belt drying, freeze-drying and airdrying. Food Chemistry, 11(1), 1-6. http://dx.doi.org/10.1016/j. foodchem.2007.02.029.

Kotwaliwale, N., Bakane, P., \& Verma, A. (2007). Changes in textural and optical properties of oyster mushroom during hot air drying. Journal of Food Engineering, 7(8), 1207-1211. http://dx.doi.org/10.1016/j. jfoodeng.2005.12.033.

Neklyudov, A. D., \& Ivankin, A. N. (2007). Collagen: production, properties and application (pp. 336). Moscow: Publishing House MGUL.

Nireesha, G., Divya, L., Sowmya, C., Venkateshan, N., Niranjan, B. M., \& Lavakumar, V. (2013). Lyophilization/freeze drying-an review. International Journal of Research in Pharmaceutical Sciences, 3, 87-98.

Papavasiliou, G., Kourkoutas, Y., Rapti, A., Sipsas, V., Soupioni, M., \& Koutinas, A. A. (2008). Production of freeze-dried kefir culture using whey. International Dairy Journal, 18(3), 247-254. http:// dx.doi.org/10.1016/j.idairyj.2007.09.005.

Singh, T. A., Sarangi, P. K., \& Singh, N. J. (2018). Tenderisation of meat by bromelain enzyme extracted from pineapple wastes. International Journal of Current Microbiology and Applied Sciences, 7(9), 32563264. http://dx.doi.org/10.20546/ijcmas.2018.709.404.

Skurikhin, I. M., \& Tutelyan, V. A. (1998). A guide to the methods of analyzing food quality and safety (pp. 23-37). Moscow: Brandes Medicine.

Spohner, S. C., Müller, H., Quitmann, H., \& Czermak, P. (2015). Expression of enzymes for the usage in food and feed industry with Pichia pastoris. Journal of Biotechnology, 202, 118-134. http://dx.doi. org/10.1016/j.jbiotec.2015.01.027. PMid:25687104.

State Committee for Standards and Product Quality Management. (1989). GOST 20264.2-88 - Enzyme preparations. Methods for determination of proteolytic activity (pp. 14). Moscow: Gosstandart.

Vidal, A. R., Ferreira, T. E., Mello, R. O., Schmidt, M. M., Kubota, E. H., Demiate, I. M., Zielinski, A. A. F., \& Dornelles, R. C. P. (2018). Effects of enzymatic hydrolysis (Flavourzyme ${ }^{\bowtie}$ ) assisted by ultrasound in the structural and functional properties of hydrolyzates from different bovine collagens. Food Science and Technology (Campinas), 38(Suppl 1), 103-108. http://dx.doi.org/10.1590/fst.16717.

Wenfeng, S., Gooneratne, R., Glithero, N., Weld, R. J., \& Pasco, N. (2013). Appraising freeze-drying for storage of bacteria and their ready access in a rapid toxicity assessment assay. Applied Microbiology and Biotechnology, 97(23), 10189-10198. http://dx.doi.org/10.1007/ s00253-013-4706-3. PMid:23377787. 